Original article

\title{
Pengaruh urea dalam media maturasi in vitro terhadap tingkat maturasi oosit sapi
}

\section{The effect of urea in in vitro maturation medium on maturation rate of bovine oocyte}

\author{
Sepvian Dewi Kurniawati ${ }^{1 *}$, Suryanie Sarudji ${ }^{2}$, Widjiati Widjiati ${ }^{3}$ \\ ${ }^{1}$ Division of Veterinary Reproduction, ${ }^{2}$ Division of Veterinary Microbiology, \\ ${ }^{3}$ Division of Veterinary Anatomy, Faculty of Veterinary Medicine, Universitas Airlangga \\ *Corresponding author, e-mail: sepvian.dewi.kurniawati-2019@fkh.unair.ac.id \\ Open access under CC BY - SA license, DOI: 10.20473/ovz.v10i2.2021.46-52 \\ Received June 27 2021, Revised July 21 2021, Accepted July 282021 \\ Published online August 172021
}

\begin{abstract}
This study was aimed to determine the effect of urea in maturation medium on in vitro oocyte maturation rate. The medium used was TCM-199 added with Hepes, $\mathrm{NaHCO}_{3}$, Kanamycin 0.15 $\mathrm{IU} / \mathrm{mL}$, PMSG, $0.15 \mathrm{IU} / \mathrm{mL}$ hCG, and 10\% FBS. Cumulus oocyte complexes (COCs) of cows derived from follicle aspiration were divided into three groups. In control group (P0), the COCs were matured in vitro in a maturation medium without urea addition, meanwhile in the $\mathrm{P} 1$ and $\mathrm{P} 2$ groups, the medium was added with urea 20 and $40 \mathrm{mg} / \mathrm{dL}$, respectively. Each petri dish contained three drops of maturation medium ( $300 \mu \mathrm{l} / \mathrm{drops})$ according to the groups. Microdrops were coated with mineral oil and then incubated in a $5 \% \mathrm{CO}_{2}$ incubator, at $39{ }^{\circ} \mathrm{C}$ with maximum humidity. Aceto-orcein staining was conducted to evaluate the maturation of oocytes based on the achievement of metaphase II phase that is indicated by the presence of metaphase plate and/or first polar body. The result showed that the oocyte maturation rates of P0, P1, and P2 were 51.25, $52.43(\mathrm{p}>0.05)$, and $46.88 \%(\mathrm{p}<0.05)$ respectively. It could be concluded that the presence of urea at $40 \mathrm{mg} / \mathrm{dL}$ in maturation medium reduced the percentage of bovine oocyte maturation in vitro.
\end{abstract}

Keywords: bovine oocyte, cumulus-oocyte complexes, in vitro maturation, TCM-199, urea

\section{PENDAHULUAN}

Peternak umumnya menambah jumlah pakan konsentrat pada sapi perahnya dengan tujuan meningkatkan produksi susu. Produk akhir metabolisme protein pada ternak ruminansia adalah urea yang kemudian beredar dalam aliran darah sebagai blood urea nitrogen (BUN) dan diekskresikan kedalam susu sebagai milk urea nitrogen (MUN) (Getahun et al., 2019). Terdapat korelasi positif antara BUN dan MUN, dan konsentrasinya dalam tubuh sapi cenderung seimbang (Batista et al., 2017). Urea dalam darah dan susu dipengaruhi oleh rasio pemberian protein. Sapi perah FH yang mendapat asupan pakan dengan rasio kosentrat/rumput lebih dari 30\% menunjukkan kadar MUN lebih tinggi, produksi susu dan performa reproduksi lebih baik dibandingkan dibandingkan sapi dengan rasio kosentrat/ rumput kurang dari 30\% (Utama et al., 2018). Batas optimum MUN secara individual pada sapi berkisar antara 8-25 $\mathrm{mg} / \mathrm{dL}$, sedangkan konsentrasi optimum BUN berkisar antara 12-18 $\mathrm{mg} / \mathrm{dL}$ (Bazet et al., 2010). Oleh karena itu, pengukuran kadar MUN maupun BUN dapat dimanfaatkan sebagai informasi penting bagi peternak tentang status gizi dan kesehatan ternak 
(Roy et al., 2011). Kadar MUN 8 sampai 12 $\mathrm{mg} / \mathrm{dL}$ adalah rentang optimum yang mencerminkan ransum yang diformulasikan untuk memenuhi kebutuhan protein sapi perah dengan produktivitas yang tinggi. Ransum tersebut disusun atas keseimbangan fraksi protein, dan karbohidrat untuk menangkap kelebihan amonia rumen, dengan kadar protein ransum sekitar $16 \%$. Kadar MUN yang rendah menggambarkan kurang optimalnya pemanfaatan kapasitas produksi susu sapi perah, sedangkan kadar MUN yang tinggi menunjukkan penggunaan asupan nitrogen yang tidak efisien untuk produksi susu (Gullinňski et al., 2016; Lavery dan Ferris, 2021).

Protein pakan yang tinggi yang berasal dari konsentrat pada sapi perah dilaporkan terkait dengan penurunan tingkat konsepsi, $\mathrm{pH}$ uterus, fungsi ovarium dan peningkatan services per conception (Rodney et al., 2018), sehingga justru dapat mengganggu kinerja reproduksi sapi perah (Fang et al., 2019). Kelebihan protein dalam pakan diatas batas maksimum akan diikuti dengan peningkatkan pembentukan urea dalam hati, peningkatkan kadar urea dalam darah, perubahan komposisi cairan dalam uterus dan penurunan conception rates (Cheng et al., 2015). Semua sapi FH dengan kadar BUN lebih dari 18 $\mathrm{mg} / \mathrm{dL}$ tidak mengalami kesulitan untuk bunting (Putri et al., 2018).

Terdapat korelasi positif yang kuat antara blood urea nitrogen (BUN) dan follicular fluid urea nitrogen (FUN). Kadar BUN dan FUN lebih tinggi pada kuda dengan folikel yang sedang tumbuh dibandingkan dengan folikel preovulasi. Kadar BUN lebih tinggi terdapat pada kuda donor yang menghasilkan embrio yang gagal menghasilkan kebuntingan dibandingkan dengan kuda donor dengan embrio yang menghasilkan kebuntingan (Boakari et al., 2021). Sehubungan dengan hal itu, maka penelitian ini bertujuan untuk membuktikan pengaruh urea dalam media maturasi in vitro terhadap penurunan persentase maturasi oosit sapi.

\section{MATERI DAN METODE}

Penelitian ini menggunakan rancangan acak lengkap terdiri atas tiga kelompok dengan yang masing-masing terdiri atas enam ulangan.
Sampel yang digunakan adalah oosit yang diperoleh dari ovarium sapi-sapi betina yang telah majir karena gangguan reproduksi pada uterusnya, yang berasal dari Rumah Potong Hewan (RPH) Pegirian, Surabaya. Sejumlah cumulus oocyte complexes (COCs) yang diperoleh dari setiap pengambilan ovarium dari RPH dibagi secara acak menjadi tiga kelompok. Pada kelompok kontrol (P0) COCs dimaturasi dalam media maturasi tanpa penambahan urea, sedangkan kelompok P1 dan P2 COCs dimaturasi dalam media maturasi dengan penambahan urea 20 dan $40 \mathrm{mg} / \mathrm{dL}$.

Maturasi oosit secara in vitro, pewarnaan oosit, dan perhitungan tingkat maturasi oosit yang matur dilakukan di Sub Laboratorium Fertilisasi In Vitro (Laboratorium Kebidanan) Fakultas Kedokteran Hewan Universitas Airlangga.

\section{Aspirasi oosit}

Ovarium sapi dibawa dari RPH dalam termos stainless. Ovarium dipisahkan dari jaringan lain menggunakan gunting bengkok. Ovarium yang sudah terpisah dicuci tiga kali dengan Phosphate Buffered Saline (PBS) dengan suhu $39^{\circ} \mathrm{C}$. Cairan folikel diaspirasi dari folikel yang mempunyai ukuran 2-8 $\mathrm{mm}$ dengan menggunakan syringe $10 \mathrm{~mL}$ dan jarum 18 gauge yang berisi media dissection yang mengandung TCM-199, Hepes, dan Kanamycin monosulphate dengan pH 7,4, osmolaritas $279 \mathrm{mOsm} / \mathrm{kg} \mathrm{H}_{2} \mathrm{O}$ dan ditambah FBS 10\% (Kartikasari et al., 2020).

Cairan hasil aspirasi didiamkan selama 5 menit di dalam tabung untuk mengendapkan COC. Cairan hasil aspirasi diambil hingga tersisa sedikit diatas endapan COCs di bagian dasar tabung, endapan COC dan sisa cairan dalam tabung dituang pada petri dish $100 \mathrm{~mm}$ yang sudah diberi garis bantu. Seleksi oosit menggunakan mikrosop dissecting dengan perbesaran 100-200 x, dan dilakukan pencucian dan seleksi COCs yang mempunyai sitoplasma homogen serta masih mempunyai minimal tiga lapis sel cumulus yang padat. Hasil seleksi dipindahkan ke media dissection di petri dish 60 $\mathrm{mm}$, lalu diseleksi kembali dan COCs dipindahkan ke media dissection di petri dish $35 \mathrm{~mm}$ (Kartikasari et al., 2020). 


\section{Maturasi oosit in vitro}

Cumulus oocyte complexes (COCs) yang sudah diseleksi dari media dissection dipindahkan ke dalam tetes (drop) media maturasi. Media maturase yang digunakan adalah media TCM-199, dengan penambahan Sodium bicarbonate, Kanamycin monosulphate, dan Hepes dengan $\mathrm{pH} 7,8$, osmolaritas 280 $\mathrm{mOsm} / \mathrm{kg} \mathrm{H} 2 \mathrm{O}$ dan ditambahkan FBS $10 \%$, PMSG 0,15 IU/mL, hCG $0,15 \mathrm{IU} / \mathrm{mL}$. Setiap petridish dibuat tiga drop media maturasi (300 $\mu \mathrm{l} /$ drop) yang dilapisi mineral oil kemudian telah diinkubasi minimal 2 jam sebelum maturasi pada inkubator $\mathrm{CO} 25 \%$, kelembaban maksimal, suhu $39^{\circ} \mathrm{C}$ selama 24 jam (Kartikasari et al., 2020).

\section{Perwarnaan aceto-orcein}

Sel kumulus yang mengelilingi oosit dihilangkan dengan cara dipipet berulang-ulang menggunakan mikropipet dalam media dissection yang mengandung hyaluronidase 100 $\mathrm{IU} / \mathrm{mL}$. Oosit yang telah bebas dari sel cumulus difiksasi dengan cara oosit diletakkan di atas gelas obyek yang telah diberi campuran parafin wax dan vaselin (1:9) pada bagian samping tepi, kemudian ditutup dengan cover glass. Cover glass ditekan sedikit agar oosit agak terjepit sehingga tidak lepas pada saat fiksasi, pewarnaan dan pencucian. Setelah oosit terjepit gelas obyek dimasukkan ke dalam staining jar berisi larutan asam asetat-methanol (1:3) minimal selama 24 jam. Setelah difiksasi oosit diwarnai dengan aceto-orcein $1 \%$ dan dicuci dengan aceto-glycerol-aquades (1:1:3) (Kartikasari et al., 2020).
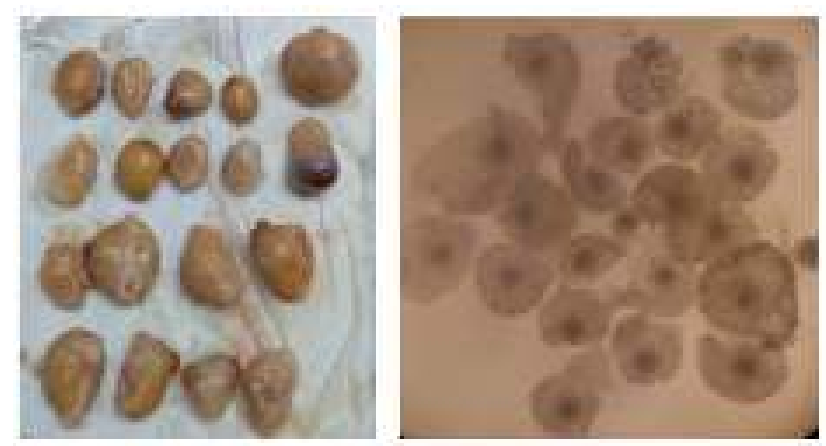

Gambar 1 Ovarium sapi setelah dibersihkan dari jaringan sekitarnya (kiri), dan cumulus oocyte complex sapi (kanan) diperiksa menggunakan mikroskop Inverted Olympus perbesaran 100x.

\section{Pengamatan oosit matur}

Perhitungan tingkat maturasi oosit didasarkan atas tercapainya fase metaphase II setelah 20 jam maturasi in vitro. Identifikasi oosit yang mencapai fase metaphase II dilakukan dengan pewarnaan aceto-orcein, selanjutnya oosit diobservasi dengan mikroskop inverted. Oosit dalam fase metaphase II ditandai dengan terlihatnya metaphase plate dan/atau polar body I (Bahrami et al., 2019). Tingkat maturasi oosit dihitung dalam pesentase, yaitu jumlah oosit matur dibagi jumlah oosit yang dimaturasi dikali 100\% (Kartikasari et al., 2020).

\section{Analisis data}

Data dianalisis menggunakan Analysis of Variance (ANOVA) dilanjutan dengan uji-t dengan dua sampel dengan asumsi varians sama pada tingkat kepercayaan 95\%. Analisis statistik dilakukan dengan perangkat lunak Statistical Program and Service Solution (SPSS) Versi 23.

\section{HASIL}

Pada penelitian ini dilakukan enam kali pengambilan ovarium, dan diperoleh 10-18 pasang ovarium setiap kali pengambilan. Ovarium setelah dibersihkan dari jaringan sekitarnya dan COCs hasil aspirasi folikel dapat dilihat pada Gambar 1, sedangkan hasil pewarnaan menggunakan aceto-orcein pada oosit disajikan pada Gambar 2. Jumlah COCs, jumlah oosit matur, dan persentase oosit matur setelah maturasi in vitro dengan penambahan urea pada media maturasi dapat dilihat pada Tabel 1.
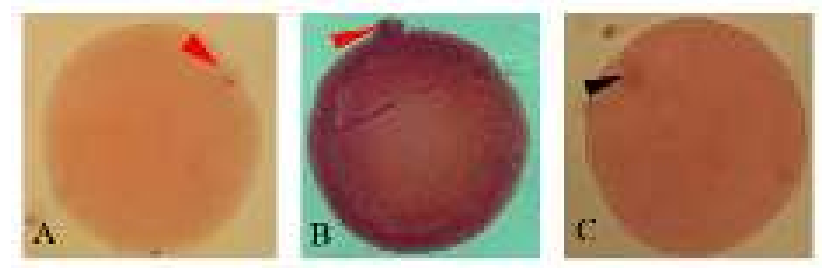

Gambar 2 Oosit sapi matur menunjukkan polar body I (kepala panah merah), dan metaphase plate (kepala panah hitam); $\mathrm{A}=$ kontrol, oosit dimaturasi tanpa penambahan urea; $\mathrm{B}, \mathrm{C}=$ maturasi dengan penambahan urea 20 dan 40 $\mathrm{mg} / \mathrm{dL}$ dalam media maturasi (pewarnaan acetoorcein; mikroskop Inverted Olympus perbesaran 400x). 
Tabel 1 Tingkat maturasi (\%, rata-rata \pm SD) in vitro oosit sapi dengan penambahan urea pada media maturasi.

\begin{tabular}{llll}
\hline & A & B & maturasi (\%) \\
\hline P0 & 82 & 42 & $51,25 \pm 4,25^{\mathrm{a}}$ \\
P1 & 82 & 43 & $52,43 \pm 5,45^{\text {a }}$ \\
P2 & 75 & 35 & $46,88 \pm 4,28^{\mathrm{b}}$ \\
\hline
\end{tabular}

Superskrip yang berbeda pada kolom yang sama memperlihatkan perbedaan yang nyata $(\mathrm{p}<0,05)$; $\mathrm{A}=$ jumlah $\mathrm{COCs} ; \mathrm{B}=$ jumlah oosit matur; $\mathrm{P} 0=$ oosit dimaturasi tanpa penambahan urea; $\mathrm{P} 1=$ oosit dimaturasi dengan penambahan urea 20 $\mathrm{mg} / \mathrm{dL} ; \quad \mathrm{P} 2=$ oosit dimaturasi dengan penambahan urea $40 \mathrm{mg} / \mathrm{dL}$; ulangan $=6$.

\section{DISKUSI}

Pada sapi perah, asupan protein yang tinggi menyebabkan peningkatan amonia dalam rumen yang selanjutnya meningkatkan pembentukan urea dalam hati, meningkatkan kadar urea dalam darah (BUN) dan dalam susu (MUN) (Xia et al., 2018). Tinggi rendahnya kadar MUN berkorelasi dengan kadar IGF-1 (Ardiansyah et al., 2019) dan kadar estrogen (Jannah et al., 2019). Kadar IGF-1 dan estrogen mempengaruhi pertumbuhan dan maturasi folikel pada sapi (Velazquez et al., 2009). Proses maturasi inti berhubungan dengan aktivitas sintesis RNA. Membran inti akan mengadakan penyatuan dengan vesicle membentuk GV dan kemudian akan mengalami pelepasan membran inti membentuk GVBD. Oosit yang telah mengalami GVBD selanjutnya akan mencapai tahap MI. Oosit yang berada pada tahap MII merupakan oosit yang telah matur dan ditandai dengan terbentuknya polar body I (Lee et al., 2019).

Pada penelitian ini oosit yang mempunyai sitoplasma homogen serta masih mempunyai tiga lapis sel cumulus utuh atau lebih yang diproses maturasi (Gambar 1). Kualitas oosit merupakan faktor yang sangat penting dalam menentukan maturasi oosit. Oosit dengan sel kumulus utuh menjaga oosit dan berperan selama tahapan pembelahan meiosis serta mendukung maturasi sitoplasma. Kurangnya selsel kumulus akan menyebabkan penurunan metabolisme dan mengakibatkan tidak tersedianya nutrisi yang sangat dibutuhkan selama proses maturasi (Daoed et al., 2013).
Keberadaan sel kumulus dapat mendukung maturasi oosit melalui zat metabolit. Sel-sel kumulus berperan menyediakan nutrisi bagi oosit serta membantu sintesis protein untuk pembentukan zona pelusida. Ekspansi kumulus berkorelasi dengan GVBD (Da Broi et al., 2018). Berdasarkan hal tersebut, terjadinya ekspansi sel-sel kumulus dapat memperkirakan terjadinya maturasi oosit secara in vitro (Del Collado et al., 2017). Cairan folikel berperan dalam proses maturasi oosit serta mempunyai zat vital untuk proses perkembangan embrio (Da Broi et al., 2018).

Maturasi oosit secara in vitro adalah sebuah proses yang dipengaruhi oleh individual oosit, yang disebabkan oleh adanya perbedaan dalam perkembangan dan pertumbuhan oosit yang dikoleksi dari ovarium dengan aktivitas intraovarian (Conti dan Franciosi, 2018). Faktor lain yang menyebabkan yakni kondisi kultur dan penambahan hormon dan media kultur (Mbemya et al., 2018), misalnya dengan penambahan serum buatan, foetal bovine serum (Widyastuti et al., 2015), maupun Follicle Stimulating Hormone (FSH) dan Pregnant Mare's Serum Gonatrotropin (PMSG) (Dianti et al., 2011). Media yang disuplementasi dengan serum perkembangan oosit lebih banyak dibandingkan media tanpa serum. Kandungan growth factor, hormon dan peptida dalam serum diduga dapat mendukung pertumbuhan dan perkembangan oosit (Puri et al., 2015). Suplemen yang digunakan dan kondisi kultur yang baik menunjang dalam meningkatkan kemampuan maturasi oosit secara in vitro (Daoed et al., 2013). Pada penelitian ini paparan urea 40 $\mathrm{mg} / \mathrm{dL}$ pada media maturasi oosit menyebabkan penurunan persentase oosit matur. Kadar BUN yang tinggi tinggi dapat mempengaruhi proses maturasi oosit, mengubah komposisi cairan dalam uterus, menurunkan $\mathrm{pH}$ uterus dan mengurangi conception rates (Cheng et al., 2015). Urea dalam darah dapat berpindah melalui proses difusi pasif melalui pembatas antara darah-folikel (Baura, 2021). Urea yang masuk ke cairan folikel bersifat toksik dan dapat dapat merusak membran sel oosit. Sel granulosa oosit yang terpapar ammonia dengan kadar tinggi dapar mengurangi kemampuannya untuk mendukung proses maturasi oosit secara in vitro (Nandi et al., 2018). Kadar urea yang tinggi 
dalam darah dapat menginduksi denaturasi protein dan asam nukleat sehingga kehilangan struktur sekunder dan struktur tersiernya (Lambert dan Draper, 2012), karena perubahan konformasi ikatan hidrogen pada kutubnya (Wang et al., 2014).

Urea dapat menyebabkan kematian pada oosit dengan cara merusak sistem membran pada oosit (Kowsar et al., 2018a), yang menyebabkan stres oksidatif yang dapat memicu kegagalan maturasi oosit (Mihalas et al., 2017). Urea dapat mengalami docking pada ZP-N domain, suatu protein spesifik pada zona pellucida sehingga mengganggu stabilitas homeostasis oosit. Urea bersifat cytotoxic dan mampu merusak beberapa asam amino pada oosit dan mengurangi ATP yang berperan untuk kelangsungan hidup oosit (Kowsar et al., 2018a). ATP dapat digunakan untuk menyimpan dan mentranspor energy dalam sel. Kerusakan pada oosit membuat oosit harus meningkatkan ATP intraseluler dengan proses oksidasi fosforilasi serta peningkatan laju glikolisis anaerob. Akibat peningkatan laju glikolisis anaerob, terjadi akumulasi asam laktat yang secara cepat akan menyebabkan penurunan $\mathrm{pH}$ intraseluler (Melkonian dan Schury, 2020). Penurunan $\mathrm{pH}$ intraseluler akan menyebabkan kerusakan berupa lisis membran organel, lisis membran inti, dan kerusakan kromatin inti sel berupa clumping/pemadatan inti sel secara cepat (Miller dan Zachary, 2017). Inti sel yang rusak berkaitan dengan sintesis RNA, jika kondisi kerusakan terjadi terus-menerus, maka sel akan mati dan mengalami nekrosis (Surova dan Zhivotovsky, 2013).

Perlakuan paparan urea pada saat maturasi akan mempengaruhi perkembangan embrio, sedangkan bila paparan urea diberikan pada saat fertilisasi tidak berpengaruh terhadap perkembangan embrio. Penambahan urea pada media maturasi dapat mengubah kompetensi oosit dan menginduksi ketidakseimbangan faktor transkripsi inti sel yang berakibat menjadi blastosis yang tidak sempurna (Kowsar et al., 2018b).

\section{KESIMPULAN}

Keberadaan urea $40 \mathrm{mg} / \mathrm{dL}$ pada media TCM-199 menurunkan persentase maturasi oosit sapi secara in vitro.

\section{DAFTAR PUSTAKA}

Ardiansyah M, Damayanti TD, Suprayogi TW, Mustofa I, Ismudiono I, Wurlina W. 2019. Correlation Between the Level of Milk Urea Nitrogen (MUN) when Insemination with Pregnancy Rate and IGF-1 Profile on Frisian Holstein Dairy Cow. Indian J Public Health Res Dev. 10: 2069-73.

Bahrami M, Morris MB, Day ML. 2019. Amino acid supplementation of a simple inorganic salt solution supports efficient in vitro maturation (IVM) of bovine oocytes. Sci Rep. 9: 11739.

Batista ED, Detmann E, Valadares Filho SC, Titgemeyer EC, Valadares RFD. 2017. The effect of CP concentration in the diet on urea kinetics and microbial usage of recycled urea in cattle: a meta-analysis. Animal 11: 1303-11.

Baura G. 2021. Hemodialysis delivery systems, in: Baura G (Ed.). Medical Device Technologies. $2^{\text {nd }}$ Ed. Academic Press. 22955.

Bazet MA, Huque KS, Sarker NR, Hossain MM, Islam MN. 2010. Evaluation of Milk Urea Nitrogen of dairy cows reared under different feed bases in the different seasons. J. Sci. Found. 8: 97-110.

Boakari YL, El-Sheikh Ali H, Schnobrich M, Lofrumento K, Scoggin C, Bradecamp E, Scoggin K, Esteller-Vico A, Claes A, Lawrence L, Ball B. 2021. Relationships between blood and follicular fluid urea nitrogen concentrations and between blood urea nitrogen and embryo survival in mares. Theriogenology 160: 142-50.

Cheng Z, Oguejiofor CF, Swangchan-Uthai T, Carr S, Wathes DC. 2015. Relationships between Circulating Urea Concentrations and Endometrial Function in Postpartum Dairy Cows. Animals (Basel) 5: 748-73.

Conti M, Franciosi F. 2018. Acquisition of oocyte competence to develop as an embryo: integrated nuclear and cytoplasmic events, Hum Reprod Update. 24: 245-66.

Da Broi MG, Giorgi VSI, Wang F, Keefe DL, Albertini D, Navarro PA. 2018. Influence of follicular fluid and cumulus cells on oocyte quality: clinical implications. J Assist Reprod Genet. 35: 735-51. 
Daoed DM, Ngadiyono N, Widayati DT. 2013. Effect of Fetal Calf Serum Supplementation on In Vitro Maturation Ability of Bovine Oocytes. Buletin Peternakan 37: 136-42.

Del Collado M, da Silveira JC, Oliveira MLF, Alves BMSM, Simas RC, Godoy AT, Coelho MB, Marques LA, Carriero MM, Nogueira MFG, Eberlin MN, Silva LA, Meirelles FV, Perecin F. 2017. In vitro maturation impacts cumulus-oocyte complex metabolism and stress in cattle. Reproduction. 154: 881-93.

Dianti D, Udin Z, Jaswandi J. 2011. Pengaruh Penambahan Follicle Stimulating Hormone (FSH) dan Pregnant Mare's Serum Gonatrotroprn (PMSG) dalam Sel Granulosa terhadap konsentrasi Progesteron pada Tingkat Maturasi Oosit. Jurnal Peternakan Indonesia, 13: 1-6.

Fang LH, Jin YH, Jeong JH, Hong JS, Chung WL, Kim YY. 2019. Effects of dietary energy and protein levels on reproductive performance in gestating sows and growth of their progeny. J Anim Sci Technol. 61: 154-62.

Getahun D, Alemneh T, Akeberegn D, Getabalew M, Zewdie D. 2019. Urea Metabolism and Recycling in Ruminants. Biomed J Sci \& Tech Res 20: 14790-6.

Gullinňski P, Salamończyk E, Młynek K. 2016. Improving Nitrogen Use Efficiency of Dairy Cows in Relation to Urea in Milk - A Review. Anim Sci Pap Rep. 34: 5-24.

Jannah M, Mustofa I, Utama S, Mulyati S, Ismudiono I, Safitri E, Al-Arif MA. 2019. Identification of Estrogen Levels in Dairy Cows Based on MUN Levels and Pregnancy Rates. Indian J Public Health Res Dev. 10: 1834-8.

Kartikasari D, Mulyati S, Utama S, Srianto P, Widjiati W, Plumeriastuti P. 2020. The effect of urea suplementation in maturation media of bovine oocyte in vitro towards expression of BAX, BCL-2 and BAX/BCL2 ratio. J Ked Hewan 14: 16-20.

Kowsar R, Izadi F, Sadeghi N, Riasi A, Zadegan FG, Hajian M, Nasr-Esfahani MH, Farrokhpour H, Miyamoto A. 2018a. Urea changes oocyte competence and gene expression in resultant bovine embryo in vitro. Zygote 26: 207-19.
Kowsar R, Iranshahi VN, Sadeghi N, Riasi A, Miyamoto A. 2018b. Urea influences amino acid turnover in bovine cumulus-oocyte complexes, cumulus cells and denuded oocytes, and affects in vitro fertilization outcome. Sci Rep. 8: 12191.

Lambert D, Draper DE. 2012. Denaturation of RNA secondary and tertiary structure by urea: simple unfolded state models and free energy parameters account for measured mvalues. Biochemistry 51: 9014-26.

Lavery A, Ferris CP. 2021. Proxy Measures and Novel Strategies for Estimating Nitrogen Utilisation Efficiency in Dairy Cattle. Animals 11: 343.

Lee JB, Lee MG, Lin T, Shin HY, Lee JE, Kang JW, Jin DI. 2019. Effect of oocyte chromatin status in porcine follicles on the embryo development in vitro. AsianAustralas J Anim Sci. 32: 956-65.

Mbemya GT, Cadenas J, Ribeiro de Sá NA, Damasceno Guerreiro D, Donfack NJ, Alberto Vieira L, Canafístula de Sousa FG, Geraldo Alves B, Lobo CH, Santos FW, Lima Pinto FDC, Loiola Pessoa OD, Smitz J, Comizzoli P, Figueiredo JR, Rodrigues APR. 2018. Supplementation of in vitro culture medium with FSH to grow follicles and mature oocytes can be replaced by extracts of Justicia insularis. PLoS One 13: 1-21.

Melkonian EA, Schury MP. 2020. Biochemistry, Anaerobic Glycolysis. In: StatPearls [Internet]. Treasure Island (FL): StatPearls Publishing.

Mihalas BP, Redgrove KA, McLaughlin EA, Nixon B. 2017. Molecular Mechanisms Responsible for Increased Vulnerability of the Ageing Oocyte to Oxidative Damage. Oxid Med Cell Longev. 2017: 4015874.

Miller MA, Zachary JF. 2017. Mechanisms and Morphology of Cellular Injury, Adaptation, and Death. In: JF Zachary, Ed. Pathologic Basis of Veterinary Disease. 2-43.

Nandi S, Tripathi S, Gupta P, Mondal S. 2018. Nutritional and metabolic Stressors on ovine oocyte development and granulosa cell functions in vitro. Cell Stress Chaperones 23: 357-71.

Puri G, Chaudhary SS, Singh VK, Sharma AK. 2015. Effects of fetal bovine serum and 
estrus buffalo serum on maturation of buffalo (Bubalus bubalis) oocytes in vitro. Vet World 8: 143-6.

Putri KY, Srianto P, Lestari TD, Utama S, Wurlina W, Mustofa I. 2018. Reproductive efficiency and serum progesterone concentration on dairy cattle based on blood urea nitrogen (BUN) concentrations. Iraqi J Vet Sci. 32: 143-8.

Rodney RM, Celi P, Scott W, Breinhild K, Santos JEP, Lean IJ. 2018. Effects of nutrition on the fertility of lactating dairy cattle. J Dairy Sci 101: 5115-33.

Roy B, Brahma B, Ghosh S, Pankaj PK, Mandal G. 2011. Evaluation of Milk Urea Concentration as Useful Indicator for Dairy Herd Management: A Review. Asian J Anim Vet Adv 6: 1-19.

Surova O, Zhivotovsky B. 2013. Various modes of cell death induced by DNA damage. Oncogene 32: 3789-97.

Utama S, Mulyati S, Wurlina W, Mustofa I. 2018. Effect of concentrate to forage ratio on milk urea nitrogen, milk production and reproductive performance of dairy cows. Philipp J Vet Med. 55: 25-34.
Velazquez MA, Zaraza J, Oropeza A, Webb R, Niemann H. 2009. The role of IGF1 in the in vivo production of bovine embryos from superovulated donors. Reproduction 137: 161-80.

Wang C, Chen Z, Hong X, Ning F, Liu H, Zang $\mathrm{J}$, Yan X, Kemp J, Musselman CA, Kutateladze TG, Zhao R, Jiang C, Zhang G. 2014. The structural basis of urea-induced protein unfolding in $\beta$-catenin. Acta Crystallogr D Biol Crystallogr. 70: 2840-7.

Widyastuti, R., R. Setiawan dan S.D. Rasad, S.D. 2015. Perbandingan Tingkat Kematangan Inti Oosit Sapi Pasca Maturasi In Vitro dengan Penambahan Serum Buatan 10 \% dan Fetal Bovine Serum 10 \%. J Ilmu Ternak, 15: 28-32.

Xia C, Aziz Ur Rahman M, Yang H, Shao T, Qiu Q, Su H, Cao B. 2018. Effect of increased dietary crude protein levels on production performance, nitrogen utilisation, blood metabolites and ruminal fermentation of Holstein bulls. Asian-Australas J Anim Sci. 31: 1643-53. 